\title{
Human Milk Fortifier with Higher Energy for Preterms: Beneficial or Not?
}

\author{
Ceyhun Dalkan' (D, Fahri Ovalı² (1) \\ 'Department of Pediatrics, Division of Neonatology, Near East University School of Medicine, Nicosia, Cyprus, \\ 2Department of Pediatrics, Division of Neonatology, Medeniyet University School of Medicine, İstanbul, Turkey
}

ORCID iDs of the authors: C.D. 0000-0003-4I56-9706; F.H.O. 0000-0002-97I7-3I3X.

Cite this article as: Dalkan C, Ovalı F. Human Milk Fortifier with Higher Energy for Preterms: Beneficial or Not?. Cyprus J Med Sci 2020; 5(2): 163-6.

\section{BACKGROUND/AIMS}

Human milk(HM) is considered to be the best nutrient for premature infants, it is usually inadequate to support the appropriate growth rate and it is frequently supplemented with a human milk fortifier to supply more energy and other nutrients. However, in spite of this supplementation, some infants still fall short of the expected growth rate. Additional calories provided by maltodextrin could help such infants to grow better was hypothesised in this research.

\section{MATERIAL and METHODS}

Preterms of less than 34 weeks of gestation and weighing less than $1500 \mathrm{~g}$, were evaluated. The infants were randomly placed into two groups while receiving $100 \mathrm{ml} / \mathrm{kg}$ human milk. Group I infants received human milk mixed with protein and Group 2 infants received human milk mixed with protein plus maltodextrin. This regimen continued minimum 15 and maximum 29 days and the body weight, height and head circumference measurments were recorded.

RESULTS

A total of 187 preterm infants were analysed, 46 infants were excluded from the study, while the remainder were randomly placed into two groups, respectiveley. Their gestational age, birthweight, first day of nutrition, consumption and duration of feeedings were all comparable. There were no significant differences between their weight, height and head circumference gains on the 28th day. There were also no significant differences between their serum blood urea nitrogen, albumin, calcium, phosphorus, alkaline phosphatase, sodium, potassium, chloride, thyroid stimulating hormone and free T4 levels.

\section{CONCLUSION}

Although the addition of HMF increases weight gain in premature infants, the added calories do not provide any statistically significant but better growing paterns.

Keywords: Calorie, fortification, growth rate, preterm, protein

\section{INTRODUCTION}

Body and Brain development are crucial for newborns, particularly for preterm infants, therefore inadequate feeding during the developmental period can negatively affect the short- and long-term outcomes. Therefore, adequate feeding is essential for preterm infants for optimal growth (I-4).

The postnatal growth rates of preterm infants should be the same as the intrauterine growth rate (3). The American Academy of Pediatrics (AAP) and the World Health Organization recommend breast milk for all newborns $(5,6)$. However, the inadequate protein and mineral intake from breast milk by preterm infants has previously been documented, and most of the time it is not sufficient to maintain the appropriate growth rate $(7,8)$. Therefore, breast milk is frequently enriched with a breast milk fortifier to provide more energy and other nutrient supplements. According to recommendations of the AAP and the ESPGAN, the protein intake of preterm babies should be increased to $4-4.5 \mathrm{gr} / \mathrm{kg} / \mathrm{day}(3,4)$. In addition to protein intake, calorie requirements are also higher for preterm babies according to the same recommendations $(3,4)$. Moreover, breast milk calorie intake may be inadequate to meet the required daily amount of $105-135 \mathrm{kcal} / \mathrm{kg} /$ day for preterm babies $(3,4)$. 
Although breast milk fortifiers provide more energy and protein than breast milk alone, they may not provide adequate growth requirements for preterm babies. Increasing the volume of milk to be consumed may also cause hypervolemia in preterm infants. In this study, we investigated whether increasing the calorie intake of preterm infants from $77 \mathrm{kcal} / 100 \mathrm{~mL}$ to $99 \mathrm{kcal} / 100 \mathrm{~mL}$ by adding fortifiers in breast milk would result in better growth rates.

\section{MATERIAL and METHODS}

This study was conducted at the Neonatal Intensive Care Unit between June 2009 and March 2010. The preterm infants included in the study were all small-for-gestational-age infants, less than 34 weeks of gestational age, and less than 1500 gr in birth weight. One hundred and eighty-seven preterm infants were evaluated. Infants who: had congenital anomalies, suffered perinatal asphyxia, had undergone a major surgical operation, had sepsis, were not feeding exclusively on breast milk were excluded from the study. The study was approved by the Ethics Committee of the Hospital (No:24/04/2009-28) and written informed consent was obtained from the parents of the infants included in the study.

All the participants were weighed daily, while the height and head circumferences ( $\mathrm{HC}$ ) were measured weekly. Participants were monitored for at least 15 days or until they were 29 days old. All participants were fed breast milk only and daily intakes were increased by $20 \mathrm{ml} / \mathrm{kg} /$ day until the infant received up to $200 \mathrm{ml} / \mathrm{kg}$. Once the participants were receiving up to $100 \mathrm{ml} /$ $\mathrm{kg}$ of breast milk, they were randomly assigned to two groups. Group I infants, the control group, received breast milk mixed with HMF (Eoprotin) in a ratio of I spoon per $30 \mathrm{~mL}$; while Group 2 infants, the study group, received breast milk mixed with HMF (Eoprotin) in a ratio of I spoon per $30 \mathrm{ml}$ in addition to $1 / 2$ a spoon of maltodextrin powder (Fantomalt) per $30 \mathrm{~mL}$. Following the enrichment of the breast milk in two distinct ways, the caloric intake for Group I was $77 \mathrm{kcal} / 100 \mathrm{~mL}$ and $99 \mathrm{kcal} / 100 \mathrm{~mL}$ for Group 2. Blood urea nitrogen (BUN) calcium, magnesium, alkaline phosphatase, sodium, potassium, and chloride levels were monitored on the ${ }^{\text {st }}$ day, $15^{\text {th }}$ day, and $29^{\text {th }}$ day. Thyroid-stimulating hormone (TSH) and free T4 levels were checked on the IOth day of life. In addition, gastrointestinal side effects (abdominal distension, gastric residue, vomiting, feeding intolerance, diarrhea), allergy, sepsis, and other problems were noted.

\section{Statistical Analysis}

Statistical analysis was performed using the NCSS 2007 software for Windows. Continuous variables were expressed as mean \pm standard deviation of the mean (SD). The results of the two groups were compared using Student's t-test for normally distributed data. To determine the relationship between principal variables and the other continuous variables, Pearson correlation or Spearman non-parametric correlation tests were

\section{Main Points:}

- $\quad$ Standard fortification techniques may not be adequate for providing enough energy and protein.

- Higher protein with higher calorie is essential for preterm growth.

- Increasing protein and calorie did not cause any gastrointestinal side effects. used. When equality of variances was not present, Kruskal Wallis and Mann-Whitney U non-parametric tests were used. Values of $p<0.05$ were considered statistically significant.

\section{RESULTS}

\section{Subjects}

The study was initially performed on 187 preterm infants aged 6-16 days. However, 10 infants were excluded from the study for not taking adequate breast milk. Furthermore, 35 infants were excluded because of side effects, while I infant was transferred to another hospital. Seventy-one preterm babies were enrolled into Group I (51\% girls, 49\% boys) and 70 preterm babies were enrolled into Group 2 (43\% girls, 57\% boys). Gestational age, birth weight, sex, onset of enteral feeding, maximum feeding volume, first day of fortification, and duration of fortified feeding in days were not significantly different between groups (Table I). The mean age at first enteral feeding (in days) was $1.9 \pm 0.47$ days in Group I and 1.95 \pm 0.21 days in Group 2, while the first day of fortification was $10.94 \pm 4.39$ days in Group I, and $10.4 \pm 4.39$ days in Group 2. Participants were fed for $23.96 \pm 6.62$ days in Group I and $21.33 \pm 7.55$ days in Group 2 with fortified breast milk.

The volume of intake of the modified breast milk by participants in both groups was maintained around the target volume of 180 $200 \mathrm{~mL} / \mathrm{kg} /$ day.

\section{Growth}

The weight gain of Group I participants and Group 2 participants was $31 \mathrm{mg} / \mathrm{kg} /$ day and $32 \mathrm{mg} / \mathrm{kg} /$ day respectively on the $14^{\text {th }}$ day of fortification; $32 \mathrm{mg} / \mathrm{kg} /$ day and $35 \mathrm{mg} / \mathrm{kg} /$ day respectively on the $28^{\text {th }}$ day of fortification. Although an increase in weight gain was noted in Group I participants, there was no statistical difference between the two groups ( $p>0.005)$. (Figure I)

\begin{tabular}{|lccc|}
\hline \multicolumn{4}{|c}{ TABLE I. Demographic and feeding characteristics of patients } \\
\hline Group I & Group 2 & P \\
\hline Gestational age (weeks) & $29.13 \pm 1.93$ & $28.91 \pm 1.95$ & 0.574 \\
Birthweight (g) & $1157.88 \pm 18932$ & $1152.15 \pm 178.85$ & 0.878 \\
Girl/boys ( $\mathrm{n} / \mathrm{n}$ ) & $37 / 34$ & $30 / 40$ & 0.404 \\
First enteral feeding (day) & $1.9 \pm 0.47$ & $1.95 \pm 0.61$ & 0.605 \\
Maximum feeding (ml/kg/gün) & $196.78 \pm 6.66$ & $198.15 \pm 3.56$ & 0.249 \\
First day of fortification (day) & $10.94 \pm 4.96$ & $10.4 \pm 4.39$ & 0.584 \\
\hline Duration of fortified feeding (day) & $23.96 \pm 6.62$ & $21.33 \pm 7.15$ & 0.076 \\
\hline
\end{tabular}

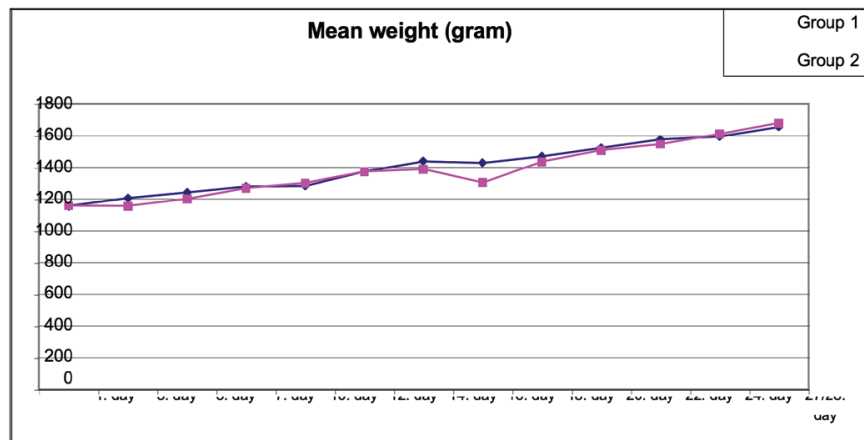

FIGURE I. Mean weights of groups 
Participants' mean height in both groups did not differ on the Ist day of fortification (37.237.2 $\pm 2.32 \mathrm{~cm}$ in Group I and $37.55 \pm 2.13 \mathrm{~cm}$ in Group 2) ( $p>0.05)$. On the $12^{\text {th }}$ day of fortification an increase in the height of participants by $1.55 \pm 0.78 \mathrm{~cm} /$ day for Group I participants and $1.31 \pm 0.72 \mathrm{~cm} /$ day for Group 2 participants $(p>0.05$ ). At the end of the study, there was no statistically significant difference between the mean height increase of participants in either group $(2.44 \pm 1.11 \mathrm{~cm} /$ day in Group I and 2.16 $\pm 1.21 \mathrm{~cm} /$ day in Group 2) ( $>>0.05)$. (Figure 2)

At the end of the study, Group 2 participants had a significantly higher HC. $(p=0.014)$. The mean HC was $27.52 \pm 2.15 \mathrm{~cm}$ in Group I and $27.34 \pm 1.56 \mathrm{~cm}$ in Group 2 ( $p>0.05)$. An increasing rate in

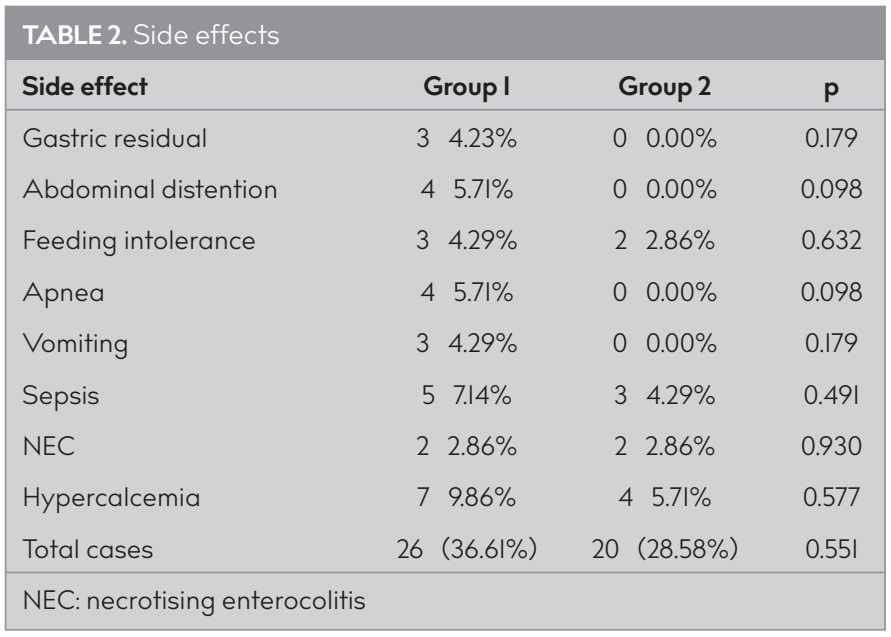

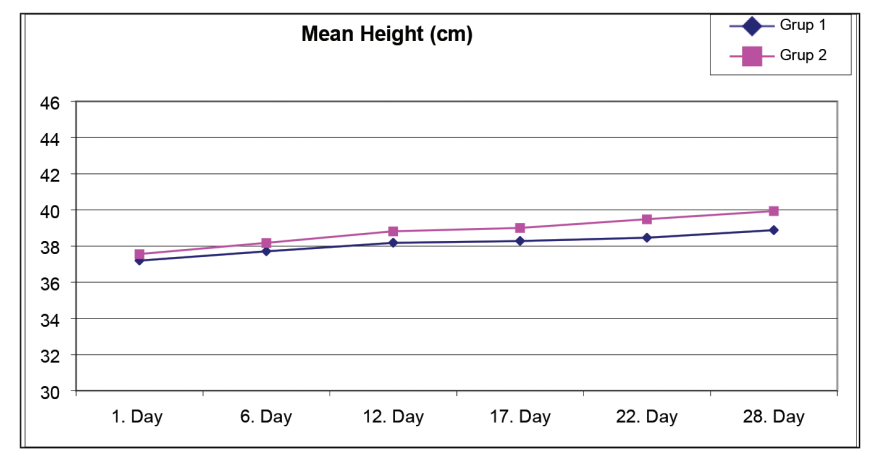

FIGURE 2. Mean heights of groups

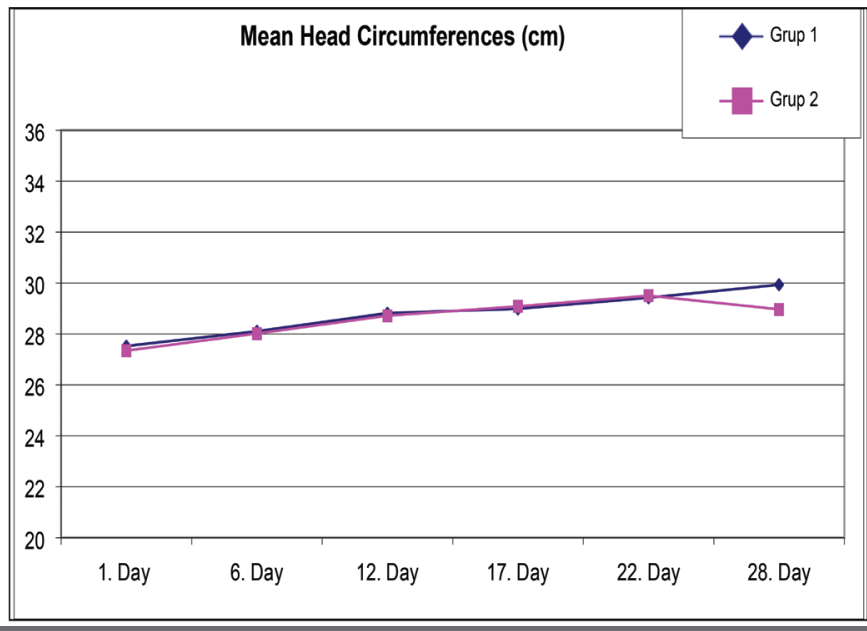

FIGURE 3. Mean head cirfumferences of groups
$\mathrm{HC}$ was not noted, $1.29 \pm 0.63 \mathrm{~cm} /$ day in Group I and $1.38 \pm 0.7 \mathrm{~cm} /$ day in Group 2 on the $12^{\text {th }}$ day of fortification. $\mathrm{HC}$ measurements were $3.19 \pm 0.79 \mathrm{~cm} /$ day in Group I and $3.89 \pm 1.15 \mathrm{~cm} /$ day in Group 2 on the $28^{\text {th }}$ day of fortification $(p=0.014)$. (Figure 3 )

\section{Serum Biochemical Data}

There was no statistically significant difference between the levels of BUN, albumin, TSH, free T4, phosphorus, magnesium, alkaline phosphatase, sodium, chloride, and potassium levels on the $\mathrm{Ist}^{\text {st }}$ $14^{\text {th }}$, and $28^{\text {th }}$ day of fortification ( $p>0.05$ ). However, although calcium levels in Group 2 participants were significantly higher, they were still within the normal ranges for preterm babies $(p=0.016)$.

\section{Feeding Tolerance and Clinical Course}

Associated side effects among the participants were not statistically significant between the two groups (Table 2). In fact, there were no statistically significant differences in any of the variables compared between the two groups. Three infants in Group I had gastric residue and 4 had abdominal distention ( $p>0.05$ ). Three infants from Group I and 2 from Group 2 had feeding intolerance $(p>0.05)$. Vomiting was only noted in 3 participants from Group I ( $p>0.05)$.

Apnea was not documented among Group 2 participants but was noted with 4 participants in Group I ( $p>0.05)$. Five participants from Group I and 3 from Group 2 had sepsis ( $p>0.05$ ). Two participants, one from each group, had necrotizing enterocolitis ( $p>0.05)$.

\section{DISCUSSION}

The AAP and the ESPGAN recommend the fortification of breast milk to increase the growth rate of preterm infants. Different fortification strategies were recommended to correct inadequacies in both the quality and quantity of protein and calorie concentrations of FHM. $(3,4)$ Standard fortification techniques may not be adequate for providing adequate energy and protein. Increasing the intake of milk may cause hypervolemia problems in preterm infants. Therefore, in order to prevent this, we added an energy provider to standard fortification to increase the caloric amount in HM. In this randomized prospective controlled trial conducted with 187 preterm infants, energy intakes were increased from $77 \mathrm{kcal} / \mathrm{L}$ to $99 \mathrm{kcal} / \mathrm{L}$; and infants' growing rate, biochemical results, and possible side effects were monitored. Adding an energy provider to HM may increase osmolarity and cause feeding intolerance and Necrotising Enterocolitis (NEC). However, there was no difference between the two groups with regards to gastrointestinal side effects. In addition, the rate of sepsis was similar in both groups. Infants provided with HMF supplemented with an energy provider had an improved growth rate, weight and height gain, and an increase in $\mathrm{HC}$ measurements when compared with the infants who were only given HMF.

In a previous study (9), two different protein-containing fortification techniques were compared using preterm infants whose weight was less than 1250 gr and had a weight gain of less than 15/ $\mathrm{gr} / \mathrm{kg} /$ day as the subjects. Daily weight gain was reported to be $17.0 \pm 2.0 \mathrm{gr} / \mathrm{kg} /$ day in the group given $3.5 \mathrm{gr} / \mathrm{kg} /$ day of protein and $11.5 \pm 4.8 \mathrm{gr} / \mathrm{kg} /$ day in the group given $3 \mathrm{gr} / \mathrm{kg} /$ day of protein at the $4^{\text {th }}$ week of fortification. However, in the current study, the infants in Group I were given fortified breast milk at $10.94 \pm 4.96$ days and Group 2 at $10.4 \pm 4.39$ days. Growth rates were found to be $33 \pm 22 \mathrm{gr} /$ $\mathrm{kg} /$ day for the Group I infants and $35 \pm 27 \mathrm{gr} / \mathrm{kg} /$ day for the Group 2 infants. The difference in the recorded growth rates between 
the preterm infants in the current study and the participants in the Brummer study may have resulted from the fact that in the current study protein-rich milk was given at an earlier age.

In a study by Mukhopadhyay et al. (10), 166 preterm infants were examined, and 2 different calorie-containing milk products were compared (66 kcal/100 mL to $79 \mathrm{kcal} / 100 \mathrm{~mL}$ ). Participants were given $150 / \mathrm{mL} / \mathrm{kg} /$ day until they weighed $2000 \mathrm{gr}$. The fortified milk-fed group was followed up to $31.9 \pm 16.2$ days and the only-breast-milkfed group was followed up to $29.4 \pm 13.2$ days. In this study, the reported growth rate was $15.1 \pm 6 \mathrm{gr} / \mathrm{kg} /$ day in the higher-calorie-given group and $12.9 \pm 4 \mathrm{gr} / \mathrm{kg} /$ day in the control group. We reported $33 \pm 22$ $\mathrm{gr} / \mathrm{kg} /$ day in the control group (Group I) and $35 \pm 27 \mathrm{gr} / \mathrm{kg} /$ day in the study group (Group2). Our preterm infants had a higher weight gain because fortification of milk products occurred earlier. In addition, the reported increase in height was $1.04 \pm 4 \mathrm{~cm} /$ week in the control group and $0.86 \pm 0.2 \mathrm{~cm} /$ week in the study group. Among the preterm infants in this study, the increase in height was observed to be $0.61 \pm 0.78 \mathrm{~cm} /$ week in the control group and $0.54 \pm 0.30 \mathrm{~cm} /$ week in the study groups. The difference in height measurements between the two studies may be due to ethnic differences.

According to the study conducted by Aslanoglu et al. (II), breast milk was fortified in three steps. Initially, $1.9 \mathrm{gr} / 100 \mathrm{~mL}$ during the study in the control group and $1.9 \mathrm{gr} / 100 \mathrm{~mL}$ of breast milk in the $\mathrm{I}^{\mathrm{st}}$ week, 2.2 $\mathrm{gr} / 100 \mathrm{~mL}$ of breast milk in the $2^{\text {nd }}$ week, and $2.3 \mathrm{gr} / 100 \mathrm{~mL}$ of breast milk in the $3^{\text {rd }}$ week in the study group were added when preterm babies were taking $100 \mathrm{~mL} / \mathrm{kg} /$ day enteral feeding and excessive breastmilk was given to the babies in the control group. Weight increase rates were reported as $24.8 \pm 4.8 \mathrm{gr} /$ day in the control group and $30.1 \pm 5.8 \mathrm{gr} /$ day in the study group. In the current study, comparatively, these rates were noted as $38.65 \pm 7.56 \mathrm{gr} /$ day in the control group and $41.37 \pm 6.29 \mathrm{gr} /$ day in the study group. The difference in weight gain by the preterm infants between the two studies may have resulted from the preterm infants' increased protein consumption, which is $3 \mathrm{gr} / \mathrm{kg} / 100 \mathrm{~mL}$ from the Ist day of fortification.

In this prospective, randomized controlled study, differences in either weight gain or rate of increase in height between the two groups of preterm infants were not statistically significant. However, the higher-energy-consuming group (Group 2) displayed an increase in height and weight by the end of the study, in addition to an improved $\mathrm{HC}$ increase rate. Side effects, especially gastrointestinal side effects, Necrotizing Enterocolitis, and feeding intolerance rates were comparable in both groups.

In conclusion, despite the better growth pattern of the higher-calorie-given group, the main factor required for the growth of preterm infants is higher protein intake. As a result of this, higher protein with higher-calorie diets are essential to achieve the same growth ratio as in utero growth in the nutritional management of preterm babies. Amino acids are important in the synthesis of insulin, insulin-like factors, and other growth-related hormones and it is reported that the lower-protein-given group shows slower growth (12-16).

Ethics Committee Approval: Ethics committee approval was received for this study from the ethics committee of Zeynep Kamil Women Health and Children Diseases Training and Research Hospital (28-24/04/2009).

Informed Consent: Written informed consent was obtained from patient who participated in this study
Peer-review: Externally peer-reviewed.

Author Contributions: Concept - C.D., F.O.; Design - C.D., F.O.; Supervision - F.O.; Resources - C.D., F.O.; Materials - C.D.; Data Collection and/or Processing - C.D.; Analysis and/or Interpretation - C.D., F.O.; Literature Search - C.D., F.O; Writing Manuscript - C.D., F.O; Critical Review - C.D., F.O.

Conflict of Interest: Authors have no conflicts of interest to declare.

Financial Disclosure: The authors declared that this study has received no financial support.

\section{REFERENCES}

I. Cooper PA, Rothberg AD, Pettifor JM, Bolton KD, Devenhuis S. Growth and biochemical responses of premature infants fed pooled preterm milk or special formula. J Pediatr Gastroent Nutr 1984; 3: 749-54. [Crossref]

2. Hay WW Jr. Aggressive nutrition of the preterm infant. Curr Pediatr Rep 2013; I: I-17. [Crossref]

3. Hulzebos $C V$, Sauer PJ. Energy requirements. Seminars in Fetal $\delta$ Neonatal Medicine 2007; 12: 2-I0. [Crossref]

4. Brown JV, Embleton ND, Harding JE, McGuire W. Multi-nutrient fortification of human milk for preterm infants.Cochrane Database Syst Rev 2016; 8(5): I-42. [Crossref]

5. American Academy of Pediatrics Committee on Nutrition. Pediatric Nutrition Handbook American Academy of Pediatrics, 2004. Ed: Kleinman RE. Nutritional needs of preterm infants. Elk Grove Village, IL: American Academy of Pediatrics; 2004.p.23-54.

6. Agostoni C, Buonocore G, Carnielli V, De Curtis M, Darmaun D, Decsi $T$, et al. Enteral nutrient supply for preterm infants: commentary from the european society for paediatric gastroenterology, hepatology, and nutrition committee on nutrition. J Pediatr Gastroenterol Nutr 20I0; 50: 85-91. [Crossref]

7. Tudehope DI. Human milk and the nutritional needs of preterm infants. J Pediatr 2013; 162(3): 17- 25. [Crossref]

8. Mark A. Underwood. Human milk for the premature infant. Pediatr Clin North Am 2013; 60(I): 189-207. [Crossref]

9. Brumberg HL, Kowalski L, Troxell-Dorgan A, Getter P, Konstantino $M$, Poulsen JF, et al. Randomized trial of enteral protein and energy supplementation in infants less than or equal to $1250 \mathrm{~g}$ at birth. J Perinatol 2010; 30: 517-2I. [Crossref]

10. Mukhopadhyay K, Narang A, Mahajan R. Effect of human milk fortification in appropriate for gestation and small for gestation preterm babies: A randomized controlled trial. Indian Pediatr 2006; 44(17): 286-90.

II. Arslanoğlu S, Moro GE, Ziegler EE. Adjustable fortification of human milk fed to preterm infants: does it make a diference?. Journal of Perinatology 2006; 26: 614-21. [Crossref]

12. Brownlee KG, Kelly EJ, Ng PC, Kendall-Smith SC, Dear PR. Early or late parenteral nutrition for the sick preterm infant? Arch Dis Child 1993; 69: 281-3. [Crossref]

13. Pauls J, Baver K, Versmold H. Postnatal body weight curves for infants below $1000 \mathrm{~g}$ birth weight receiving early enteral and parenteral nutrition. Eur J Pediatr 1998; 157: 416-21. [Crossref]

14. Lofqvist C, Engstrom E, Sigurdsson J, Hard AL, Niklasson A, Ewald $U$, et al. Postnatal head growth deficit among premature infants parallels retinopathy of prematurity and insulin-like growth factor-I deficit. Pediatrics 2006; I17: 1930-8. [Crossref]

15. Hansen-Pupp I, Hovel H, Hellstrom A, Hellstrom-Westas L, Lofqvist $C$, Larsson EM, et al. Postnatal decrease in circulating insulin-like growth factor-I and low brain volumes in very preterm infants. $J$ Clin Endocrinol Metab 20II; 96: I129-35. [Crossref]

16. Ertem D, Polat E. Riskli Bebekte Malnutrisyon Tedavisi. Akman I editor. Riskli Bebek İzlemi. İstanbul, Boyut Yayınları; 2014.p.l62-82. 